\title{
ЩО ТАКЕ ФІЛОСОФІЯ?
}

\section{Діалог Вадима Россмана і Ярослава Шрамка}

\begin{abstract}
Прудон написав книгу «Філософія убогості». Маркс відповів йому «Убогістю філософї̈». Ми часто говоримо про філософію в поезї $i$ науці, але рідше про науковість або поезію самої філософії. У діалозі двох філософів обговорюються проблеми природи філософсъкого знання, статусу філософії в сучасній культурі, а також перспективи ї розвитку. Наріжним каменем дискусіӥ постають концепиії філософії як науки $і$ філософії як поетичної творчості, співвідношення теоретичного $i$ нормативного підходів, ієрархія розділів філософії. Автори також обговорюють особливості сучасної інтелектуалъної ситуаціӥ, конвергенцію різних традицій, шкіл і напрямків, що знаменуе собою прихід своєрідної «епохи сплавів у білософії».
\end{abstract}

Я. Шрамко. Широко поширеною є думка, згідно з якою філософія переживає сьогодні далеко не кращі свої часи. Ритуальні нарікання з приводу «кризи філософії» регулярно відтворюються на шпальтах різноманітних професійних і напівпрофесійних видань і періодично озвучуються на всілякого роду форумах. Як безперечну ознаку такого сумного становища зазвичай наводять ті труднощі, з якими стикається філософія в системі вищої освіти. Навчальні години з філософії поступово скорчуються. Інколи навіть ставиться під сумнів доцільність читання цього курсу для студентів усіх спеціальностей. Філософам доводиться виборювати місце під сонцем і, відстоюючи своє право на існування, обгрунтовувати власну необхідність і значущість.

Актуальні проблеми духовності:

зб. наук. праць / Ред.: Я.В. Шрамко

Вип. 10. - Кривий Ріг, 2009, 53-83 
Подібні процеси $є$ характерними для всіх країн так званого «пострадянського простору». Тому в нашій розмові мені хотілося б порушити деякі важливі питання щодо сутності філософії, її необхідності і корисності для професійної підготовки.

В. Россман. За роки радянської влади колишня радянська людина, ймовірно, так само втомилася від філософії-як чогось настирливого і надокучливого, - як західна людина втомилася від порнографії або реклами. На Заході філософія ніколи не посідала того місця, яке вона мала в СРСР. Проте і тут після закінчення холодної війни, - не знаю, як точніше визначити цей зв'язок, але не думаю, щоб це був простий збіг, - соціальна вага філософії, як і деяких інших дисциплін гуманітарного циклу, знизилася і в суспільстві загалом, і в освітніх процесах. Курси філософсії почали ущільнювати, як, утім, і з багатьох інших гуманітарних дисциплін. Фактично занепала славістика, яка значною мірою підживлювалася коштами Пентагону. Кілька років тому одна з найбільш популярних і багатотиражних газет Великобританії Daily Telegraph опублікувала список ста геніїв, що живуть нині, троє з яких проходили під рубрикою «філософія»: Хомський, швидше лінгвіст, ніж філософ, випадкова новозеландська феміністка і перекладач Кіркегора-маловідомі і не дуже вагомі фігури. Серед тих, кого по-англійськи називають public intellectuals, практично немає філософів. Імовірно, можна говорити про певну циклічну кризу або кінець якогось важливого етапу в інтелектуально-філософському розвитку. Доволі схожі процеси мають місце і в Росії. Можливо, сьогодні втрачається і вислизає сенс самого предмета філософії, стає не зовсім ясною $\dddot{̈ і ̈ ~ п р и р о д а . ~}$

Я. Шрамко. В одному з сучасних навчальних посібників із філософії, призначеному для студентів нефілософських спеціальностей, філософія визначається як «теоретично осмислений світогляд». Таке розуміння філософії як особливого виду світогляду зараз у нас досить поширене і вважається мало не загальним місцем. На ваш погляд, наскільки це визначення і таке розуміння загалом, $є$ обгрунтованими? Чи продуктивно в цілому визначати філософію через світогляд?

В. Россман. Дійсно, саме слово «світогляд» видається дещо розпливчастим, хоча я і не вважаю його таким вже анахронізмом. Можливо, філософію і справді потрібно визначати якимось більш енергійним, активним чином. Філософія, якщо завгодно, - це особлива форма інтелектуального насильства. Тим не менше, термін «світогляд» має певні переваги, оскільки в ньому поєднуються моменти знання і цінності. 
Саме поняття світогляду передбачає наявність певного кругозору і орієнтацію на певні цінності. Цей термін є досить вдалим ще й тому, що вказує на предмет як на щось ціле, а саме цей момент сприймання цілого і виявляється упущеним в безкінечному процесі спеціалізації і дроблення знання. Відтак бачення і розуміння цілого набуває особливої ваги, а філософія, за визначенням, якраз і займається цим цілим. До того ж філософія - це не зовсім наука. У ній $є$ як науковий елемент, так і елемент поетичний, елемент мистецтва. А яке альтернативне визначення запропонували б ви?

Я.Шрамко. Дати визначення філософії, звичайно ж, надзвичайно складно, якщо це взагалі можливо. Тому я обрав би тут більш обережний спосіб висловлення і швидше вів би мову саме про «розуміння філософії, тобто про те, чим є (або має бути) філософія загалом, які завдання може (або має) ставити перед собою той, хто намагається займатися філософією і претендує на звання «філософа». Тут мені видається важливим із самого початку виділити і зафіксувати деякі ключові моменти. Перш за все, я переконаний, що основне завдання філософії- це давати нове знання. У такому разі філософія практично нічим не відрізняється від інших наук, таких як фізика, математика або історія. Тому моя відповідь на старе, але таке, що знову й знову потрапляє в центр жвавих дискусій, питання, чи є філософія наукою, загалом ствердна. Тією мірою, якою філософія здатна і повинна виробляти знання, вона, безперечно, є наукою. Інша річ, що ця наука, утім, як і будь-яка інша, має свою особливу специфіку, обумовлену особливостями її предмета, а також задіяного поняттєвого і методологічного інструментарію.

В. Россман. Дійсно, предмет філософії не так просто визначити. Історично сама конфігурація і простір філософії істотно змінювалися. Але моменти цінностей і поезії поверх знань завжди залишалися фундаментальними. Ідея цінності закладена вже в самому нормативному характері філософії. Нормативний смисл філософії проявляється вже в природі філософських питань і не тільки в галузі етики і естетики. Що в житті важливе, а що не є таким вже суттєвим; як потрібно мислити, а як мислити не можна; що слід уважати причиною, а що наслідком; як варто чинити, а як - ні; що можна вважати прекрасним, а що не можна; як людство на кожному окремому етапі усвідомлює свої задачі і як їх можна усвідомлювати. Все це-нормативні питання, а, отже, і питання про цінності. Сюди, до речі, належить також і логіка. 
Я. Шрамко. Я не погодився б з уявленням про нормативний характер філософії. У моєму розумінні нормативність передбачає продукування і навіть нав'язування тих чи тих регуляторів і цінностей. Звичайно, філософія має справу з цінностями, але вона їх не виробляє (i не повинна виробляти), а вивчає. Точніше, якщо філософія й виробляє цінності, то не більшою мірою, ніж будь-яка інша наука. Звісно, нове знання може мати і часто дійсно має для людини велику цінність. Проте, на мій погляд, було б помилкою надавати філософії право визначати, що саме для людини має бути цінністю, а що - ні. Філософія вивчає актуальні і потенційні (тобто як дійсні, так і можливі) системи цінностей і норм, але вона саме вивчає їх, а зовсім не розробляє або ж проголошує. Крім того, філософія робить об'єктом теоретичного аналізу саме поняття норми і цінності. Норми виробляються людством загалом або окремими національними, соціальними, релігійними й іншими спільнотами (групами) значною мірою стихійно, у ході, як це прийнято говорити, «історичного розвитку», вони виражаються і систематизуються за допомогою всіляких релігійних, ідеологічних, політико-правових учень, концепцій і систем, у різного роду писаних і неписаних правових і моральних «кодексах». Філософія, звичайно, повинна вивчати такі вчення, концептуальні системи, а також норми, що стихійно складаються. Можливо, вона навіть спроможна зробити свій внесок до їх оформлення (формулювання) і уточнення. Але на більше справжня філософія, на мій погляд, претендувати не може і не повинна, якщо не хоче сама перетворитися на різновид релігії або ідеології. Іншими словами, філософія, безперечно, вивчає оцінні судження, але самі судження філософії не мають (та й не повинні мати) оцінного характеру. Звичайно, зовсім обійтися без використання «оцінної термінології» у філософії дуже важко, та й навряд чи можливо. Аналогічним чином для характеристики тих або тих явищ природи часто застосовують «оцінні терміни» (говорять, наприклад, про «трагічний» землетрус або «благодатний дощ»), проте було б смішно на цій підставі підводити такі явища під моральні норми.

Важливо враховувати, що про норми і оцінки як такі можна вести мову лише стосовно людини, тобто маючи на увазі норми людської поведінки і ставлення людини до світу й інших людей. Якщо ж під нормами розуміти ті чи ті умови, яким мають відповідати певні об'єкти або структури, то філософія, звичайно ж, формулює такі умови, проте в цьому вона нічим не відрізняється від будь-якої іншої науки. Наприклад, згідно з геометрією Евкліда, найкоротшою відстанню між будьякими двома точками завжди «має бути» пряма. А в ньютонівській 
механіці постулюється, що дія «має» дорівнювати протидії. Однак навряд чи тут доречно говорити власне про норми та імперативи, хіба що в якомусь метафоричному значенні.

Коли виходити з уявлення про філософію як науку, то слід визнати, що філософія не може мати нормативного характеру, оскільки нормативних наук просто-таки не існує. Наука, по своїй суті, є сукупністю істинних суджень, а нормативні твердження не піддаються характеристиці в термінах істинності або хибності. Поняття нормативної науки $\epsilon$ не чим іншим як неокантіанським анахронізмом.

В.Россман. Мені здається, без оцінки в філософії просто неможливо обійтися. До того ж норми властиві не лише філософії, але й іншим наукам. Навіть незацікавлені дослідження, скажімо у соціальних науках, мають своїм підгрунтям певні нормативні припущення, часто імпліцитні і далеко не завжди очевидні. Багато сучасних філософських досліджень намагаються подолати крайній дуалізм між оцінками і чистими дескрипціями, який був характерний для доби Просвітництва, особливо для Юма, і в найбільш чіткій формі відстоювався британськими філософами, наприклад, метаетиками. Філософія - це завжди медитація щодо цінностей, спроба їх зважити й обгрунтувати, а логіка завжди була і залишатиметься лише допоміжною дисципліною в архітектоніці філософського знання, що, як на мене, анітрохи не зменшує її значення. Взагалі цінності не здаються мені якимись чисто суб'єктивними і внутрішньо ірраціональними категоріями, які не можна обговорювати об'єктивно і раціонально обирати, але саме в такому вигляді вони постають у дискусіях окремих аналітичних філософів, що пропонують винести цінності за межі філософських роздумів.

Істина, добро, краса й економічна користь - такі фундаментальні цінності людини. Логіка займається однією з цих цінностей - істиною - i вже тому є нормативною наукою. Отже, філософія оперує цінностями і фактами, пропущеними через горно науки, i за допомогою логічних процедур пересувається між ними. У вихолощеному варіанті деяких напрямків аналітичної філософії логіка й епістемологія, тобто суто інструментальні елементи, навпаки, посідають центральне місце. Але я, звичайно, згоден із тим, що цінностями не можна зловживати або просто їх проголошувати - у цьому і полягає відмінність філософії від релігії. Філософія прагне до загальнозначущих і універсальних думок, задля чого необхідно, по можливості, дотримуватися цінніснонейтральної позиції.

Я.Шрамко. Все ж таки доцільно проводити чітке розмежування 
між «зважуванням» цінностей та їх обгрунтуванням. Я цілком згоден з тим, що одним з найважливіших завдань філософії є теоретичне обгрунтування систем цінностей. Цим значною мірою займається етика або, якщо завгодно, такий розділ філософії як аксіологія. Проте самі по собі ці системи цінностей не належать філософії, і тому було б дещо наївно чекати від філософії якоїсь абсолютної оцінки тих або тих цінностей, тобто їх «зважування» на якихось універсальних метафізичних терезах. Таке зважування може бути лише відносним, наприклад, фахівець з етики може констатувати, що в тій або тій системі моральних норм певний учинок оцінюється як недостойний. Намагатися ж здійснити безвідносну оцінку (або переоцінку) усіх цінностей-означає вже вийти за рамки власне етики і філософії і вступити в царину практичної моралі.

Стосовно логіки зазначу, що істина вивчається цією наукою зовсім не в нормативному сенсі. Логіка ніколи не претендувала на те, щоб задавати якісь абсолютні норми для істини або ж визначати, чим вона нібито має бути. За висловом Фреге, логіка - це «наука про найзагальніші закони буття істини».

В. Россман. I такі закони, вочевидь, не можуть бути ненормативними... .

Я. Шрамко. Якраз навпаки, такі закони лише й можливі як ненормативні, адже істина розглядається логікою як абстрактний об'єкт, що має певні об'єктивні властивості і характеристики, які підлягають теоретичному дослідженню. Підкреслю, ми не виробляємо довільно ці властивості, не винаходимо їх, не нав'язуємо або вигадуємо. Вони саме вивчаються як об'єктивно існуючі закономірності; аналогічно в геометрії вивчаються об'єктивно існуючі закономірності таких абстрактних об'єктів, як геометричні фігури. Дещо спрощуючи ситуацію, це можна проілюструвати таким чином: логіка говорить нам, що якщо істинними є висловлювання «Всякий $X \in Y$ » «Всякий $Y \in Z$ », то істинним буде (саме «буде», а не «повинно бути») і висловлювання «Всякий $X$ $\epsilon Z » ;$ геометрія стверджує, що якщо пряма $a$ паралельна прямій $b$, а пряма $b$ паралельна прямій $c$, то пряма $a$ буде паралельна прямій $c$. У цих твердженнях, які є, відповідно, логічним і геометричним законами, немає нормативності ні на йоту. Це такі ж самі об'єктивні закони, як закони фізики, хімії та інших наук. Звичайно, їм цілком можна надати «модусу імперативності», стверджуючи, наприклад, що пряма $a$ «має бути» паралельною прямій $c$, але це, звичайно ж, буде не більше ніж риторичною фігурою. I якщо ми серйозно спробуємо говорити 
тут про «нормативність», то це буде якась вироджена нормативність, саме поняття нормативності виявиться тоді вихолощеним і втратить свою специфіку. Так само етика й естетика як філософські дисципліни вивчають об'єктивні характеристики таких абстрактних об'єктів як «добро» i «краса», а не вигадують або проголошують їх. Підкреслюсаме як філософські дисципліни, що, звичайно ж, не унеможливлює існування - але вже за межами власне філософії - морально-етичних або поетико-естетичних учень і доктрин. До речі, що ви маєте на увазі під «поетичним елементом у філософії»?

В. Россман. Поезія видається мені невід'ємною характеристикою філософії. Філософія завжди розвивалася як щось середнє між наукою і мистецтвом, інколи повністю пристаючи до науки або навіть зливаючись з нею, як в епоху наукової революції, або, навпаки, рухаючись синхронно з динамікою мистецтва. Коли я говорю про поезію філософiï, я маю на увазі, що філософія - це не плід якихось суто логічних конструкцій, це плід уяви, але уяви особливої-уяви філософської, більш строгої і вивіреної, яка якісно відрізняється від поетичної. До речі, історія, на мій погляд, теж потребує особливої уяви, але вже історичної (такою уявою сповна володів, наприклад, Шпенглер саме як історик). Як і поезія, філософія шукає не лише причинно-наслідкових зв'язків у світі, але й якихось інших відповідностей і співзвучностей. Як і поезія, філософія виявляє якісь ізоморфні структури в різних речах і сферах буття. I в цьому сенсі філософія також $є$ формою боротьби з ідолопоклонством, указуючи на альтернативну систему зв'язків між речами.

Продовжуючи це порівняння, можна сказати, що філософія, історія і поезія працюють з різними типами дистанцій. Історик дивиться на події з історичної дистанції: події набувають історичного сенсу і перспективи в світлі подальшої історії. Поет дивиться на події з естетичної дистанції, через одивлення ${ }^{1}$ в процесі естетичного пізнання і споглядання. Філософія також передбачає дистанцію, перспективу одивленності, невключеності в процеси зіткнення речей.

Подібно до того, як у поезії є своя філософія, свій філософський вимір, у філософії має бути своя поезія. Деякі філософи соромляться поезї і відчувають якусь незручність з приводу порівняння своєї дисципліни з поезією: поезія - це щось нестроге, не зовсім обов'язкове,

\footnotetext{
${ }^{1}$ Рос.: «остранение»-запропонований В.Б. Шкловським термін, що означає опис в художньому творі людини, предмету або явища, ніби вперше побаченого, а тому набуваючого нових ознак. Відтак навіть звичний і визнаний предмет, як всяке нове явище, може видатися незвичайним, дивним.
} 
ненаукове, апофеоз довільних метафор і випадкових співзвучностей. Та філософія завжди виходила за межі науки, за межі прямолінійного цілепокладання, за межі самого знання. Саме в цьому і полягає сенс метафізики: вона не тільки перебуває поза фізикою, але й навіть поза логікою. Філософія завжди боролася з різними ідолами, що їх Френсіс Бекон колись позначив як ідоли печери, ринку, роду і театру. Але філософія також боролася й з ідолами самої науки, ідолами самого знання - не менш небезпечними. Я назвав би їх ідолами Університету. Все це, звичайно, не означає, що філософія не причетна до знання та науки або що вона якось ворожа по відношенню до них. Але філософія сама $є$ особливим знанням, вищим рівнем рефлексії-що не обов'язково розуміти як більш цінний - багато в чому близьким до поезії. Свого часу Роман Якобсон говорив про метафору і метонімію як дві форми тропів. Метафора характерна для поезії, метонімія - для прози; можливо, синекдоха, окремий випадок метонімії (судження типу «все $є$ одне»), особливо притаманна філософії.

Звичайно, можна поствити питання: чи доречна поезія у філософії? Років тридцять тому вийшла книга американського філософа Луїса Макі, одна 3 найкращих книг про Кіркегора, - «Кіркегор. Свого роду поет», де він розглядає данського філософа як поета. Головний об'єкт критики Кіркегора - Гегель у своїй системі, до речі, також широко послуговується метафорами, зокрема й деякими метафорами Данте. I в його системі також багато поезії (звичайно, я не маю на увазі його тарабарську мову). Отже, суперечка Кіркегора з Гегелем - це також і суперечка двох поетів, що сам Кіркегор, можливо, і не усвідомлював. Ніцше - також поет і в буквальному, й у фігуральному сенсі. Але, безумовно, поезія має проникати у філософію дозовано. Одне-сказати щось для красного слівця, а зовсім інше, коли весь мовний потік підпорядковується різним метафорам і не зберігає жодної послідовності у висловлюваннях.

Я. Шрамко. Будь-яка творча діяльність потребує уяви. Не певен, що Ейнштейн зміг би прийти до своєї теорії відносності, якби не мав значної долі уяви. Думаю, що і Лобачевському, щоб сформулювати саму ідею неевклідової геометрії, також потрібно було задіяти всю свою уяву. Проте це не перетворює їх на поетів. Чому ж філософська уява обов'язково має бути поетичною?

Як на мене, набагато продуктивнішим і ближчим до суті справи може виявитися порівняння філософії з математикою. Для філософії, як і для математики, характерним $є$ граничний рівень абстракції, хо- 
ча філософська абстракція стикається із сутностями абсолютно іншого роду, ніж абстракція математична. Однак у філософії і математики є дещо спільне, те, що й відрізняє обидві ці дисципліни від інших наук. Це спільне полягає в самій природі їхніх предметів, яка має абсолютно неемпіричний характер. Дійсно, будь-яка інша наука тією чи тією мірою обов'язково спирається на емпіричну основу і лише дві дисципліни являють собою яскравий виняток і ніби парять над землеюматематика і філософія. Мені видається це доволі показовим.

В.Россман. Предмет теології теж має абсолютно неемпіричний характер.

Я.Шрамко. Так, із тим невеличким уточненням, що теологія не $\epsilon$ наукою...

В.Россман. Ви маєте рацію в тому, що наукова уява не менш принципова для науки, ніж поетична або філософська для поезї і філософії. Але тут $є$ й фундаментальна відмінність. Якби Галілей не зробив свого відкриття, то його зробив би хтось інший. Якби Ейнштейн не створив теорії відносності, то через декілька років до цієї теорії дійшли б інші учені. Якби Тесла або Марконі не винайшли радіо, це відкриття зробив би Попов. У науці весь час до одного і того ж відкриття наближається відразу кілька дослідників. Але якби Данте не написав своєї «Божественної Комедії», то її просто б не було. Ризикну стверджувати, що те ж саме стосується і філософії, хоча ця теза і менш очевидна. Якби Гегель не написав «Феноменологію духу», розвиток філософії, можливо, пішов би якоюсь іншою траєкторією. Тут зовсім інша телеологія руху. У полемічно загостреній формі й подекуди «терористичною» мовою про це багато говорили феноменологи. За висловом Хайдеггера, «наука не мислить». «Розум Едісона відрізняється від розуму мавпи не якісно, а лише кількісно», - писав Макс Шелер. Я не згоден з такою радикальною постановкою питання, але в певному сенсі «поетична» складова філософії-це якраз те, що вони могли мати на увазі. Історично філософи часто були частиною художньої богеми. У Флоренції епохи Ренесансу вони разом з художниками і поетами оточують трон покровителя мистецтв Лоренцо Медичі. В опері Леонкавалло La Boheme філософ виявляється органічною частиною артистичної богеми. Греки обділили філософію своєю музою, але дали особливу музу Кліо історії-i в цьому була їхня помилка. Але Данте вже говорить про Беатріче як про музу філософії.

Я.Шрамко. Приклади наукових відкриттів, які ви навели, мають стосунок, головним чином, до фізики. Проте, виходячи за межі 
фізики, ми, тим самим, зовсім не обов'язково виходимо за межі науки загалом. Наука надзвичайно різноманітна і не вичерпується тільки природничо-науковим знанням. У багатьох відношеннях філософія близька до класичних гуманітарних наук, таких як історія або філологія. Це стосується і порушеної вами проблеми унікальності окремих творів. У цьому плані гуманітарні науки зближуються з художньою літературою і взагалі художньою творчістю. Якби Геродот не написав своєї «Історії», то невідомо, як би виглядала сучасна історична наука, цілком можливо, що її розвиток пішов би зовсім іншою «траєкторією». Ніхто, крім Теодора Моммзена, не міг би створити його прекрасної «Римської історії», удостоєної, до речі, Нобелівської премії з літератури, і будь-яке інше дослідження цього періоду буде саме іншим дослідженням, яке не може, та й не мусить замінити собою згаданий твір Моммзена, що має цінність саме як унікальна праця саме цього автора. У фізиці ніхто не буде п'ять разів відкривати теорію відносності, але історики і філологи знов і знов пишуть статті і монографії на одні і ті ж теми, присвячені одним і тим же подіям, особам або явищам. Якщо в природничих науках основною одиницею наукового знання виступає теорія, то в гуманітарних науках це не так, і тут такою одиницею можна вважати саме окремий твір. Фізика як наука $\epsilon$, у першу чергу, сукупністю певних теорій, які по свойй суті значною мірою знеособлені, аж до того, що назви конкретних творів, у яких уперше сформульовано ті чи ті теорії, часто пам'ятають лише вузькі фахівці з історії науки. Можна бути висококваліфікованим фахівцем у галузі ньютонової механіки, не прочитавши безпосередньо «Математичні засади натуральної філософії». На відміну від цього, кожна гуманітарна наука складається саме як «мозаїка» конкретних творів, вивчення яких $є$ обов'язковим для будь-кого, хто хоче проникнути в глибини цієї науки. Гадаю, не можна стати повноцінним фахівцем 3 історії Давнього Риму, не засвоївши названу фундаментальну працю Моммзена. Все це обумовлено відмінністю між номографічною й ідеографічною складовими наукового пізнання, на яке звернули увагу неокантіанці. Філософія в цьому розумінні $є$ перехідною ланкою між природничими і гуманітарними науками, утім, як і математика. У філософії, як і в математиці, ми стикаємося із загальними концепціями, проте важливе значення має сама форма вираження цих концепцій. Думаю, якби не було Платона, теорія ідей все одно була б сформульована, нехай навіть і не в тому вигляді. Проте без платонівських діалогів сам образ філософських творів, поза сумнівом, багато в чому відрізнявся б від сучасного. Так само геометрія відбулася б і без 
Евкліда, проте не будь його «Начал», невідомо, чи користувалися б ми при побудові математичних теорій аксіоматичним методом. Отже, наукова і філософська уява - зовсім не рядоположні поняття, тут ми маємо родо-видове відношення. Інакше кажучи, філософська уява $є$ різновидом наукової, якщо останню тлумачити достатньо широко.

В. Россман. В філософії одиницею знання також є теорія або аргумент, який часто будується на якійсь аналогії. Але мені здається, ви дещо тривіалізуєте мій приклад з Ейнштейном і Данте. Усі наші дії, думки і слова - а не лише терцини Данте - індивідуальні і їх неможливо відтворити. У такому контексті, скажімо, мій розчерк пера більш унікальний, ніж будь-яке об'єктивне наукове відкриття. Але це зовсім не те, що я мав на увазі. Я сказав, що якби не було Данте, його поему не зміг би написати ніхто інший. I висловив припущення, що в цьому сенсі філософія знаходиться ближче до поезії і далі від тих базисних сил, які визначають шлях поступу науки і техніки, останні розвиваються більш передбачено і телеологічно. Філософія більш автономна по відношенню до цих базисних сил. Момент суб'єктивності у філософії $\epsilon$ значною мірою плюсом або навіть перевагою в порівнянні з наукою, для якої кардинальну значущість має винятково об'єктивність. Кант, наприклад, пише в одній зі своїх робіт «Спір факультетів» щось в такому дусі: «Було б самовпевненим бажати захопити інших внутрішньою історією перебігу моїх думок, які мають суб'єктивну вагу для мене, але не мають жодного об'єктивного значення для інших». Проте ця суб'єктивна значущість принципово важлива для Канта і для філософа взагалі.

Я.Шрамко. Загалом я просто хотів зауважити, що стосовно унікальності окремих творів філософія зближається не лише з художньою літературою, але і з будь-якою гуманітарною наукою, а отже, ця особливість не може служити аргументом проти науковості філософії і на користь її художності. Хоча цю унікальність не слід і абсолютизувати. Адже твердження, що коли б не Данте, то «Божественна комедія» в принципі не могла б бути написана, не таке вже й незаперечне. Не бачу нічого неможливого в тому, що, не будь Данте, достатньо схожий твір міг би написати якийсь інший геніальний поет. Чому б не припустити, що на той час, коли творив Данте, ідея «Божественної комедії» настільки визріла, що буквально висіла в повітрі, і Данте просто був перший, кому вдалося цю ідею втілити. Однак повернемося до питання про те, чим може і має бути справжня філософія.

В.Россман. Відзначимо, що ви якраз пропонуєте тут своє нор- 
мативне, а не, приміром, історичне бачення філософії, коли говорите про те, чим філософії належить займатися, а не про те, чим вона була історично і як філософи ставилися до проблеми цінностей. Інакше нам би довелося вилучити з філософії, скажімо, Ніцше і Сократа. У цьому вашому нормативному визначенні я не бачу абсолютно нічого поганого. Філософія - нормативна наука, і це навіть не залежить від інтенцій її творців.

Я. Шрамко. Мені здається, тут має місце певне непорозуміння. Навіть якщо я і допускаю певну долю нормативності у своєму баченні філософії, це зовсім не означає, що тим самим філософія визначається мною саме як нормативна дисципліна. Різниця між нормативним визначенням предмета якоїсь науки і визначенням предмета цієї науки як нормативної сутності є доволі очевидною. Наприклад, якщо ми «нормативно» стверджуємо, що геометрії належить вивчати не емпіричні, реально існуючі фігури, а абстрактні просторові форми, то це, звичайно ж, не означає, що тим самим геометрія визначається як нормативна наука. 3 іншого боку, цілком можливим є нормативне використання тієї ж геометрії, як і логіки, етики чи філософії, з певною «прагматичною» метою.

Далі, викладаючи своє розуміння філософії, я менш за все хотів би виступати в ролі якогось «законодавця». Чесно кажучи, я навіть не наважився б повчати філософію, чим їй, на мою думку, належить займатися. Тут я якраз значною мірою залишаюся в межах «чистої дескриптивності» і просто намагаюся адекватно відобразити, що реально являла собою справжня філософія (і перш за все, класична філософська традиція) протягом століть свого існування.

В. Россман. «Справжня філософія» вже є нормативним поняттям...

Я. Шрамко. Можливо і так, але це аж ніяк не припускає нормативності самого поняття філософії. Звичайно, історично це поняття зазнало істотних змін і до філософів часто зараховували тих, хто перебуває з філософією в досить опосередкованому зв'язку. Далеко не кожен, хто коли-небудь оголошував себе філософом або кого проголошували таким захоплені шанувальники, насправді ним був (у цьому відношенні примітною є фігура згаданого вами Ніцше). Крім того, у діяльності того або того філософа доволі трудно буває відокремити власне філософську складову від якоїсь іншої, наприклад, політичної, педагогічної або релігійної. Наприклад, той же Сократ, намагаючись у діалозі зі своїми співрозмовниками дійти до визначення поняття му- 
жності чи справедливості або прояснити взаємозв'язок між знанням і чеснотою, діяв, поза сумнівом, як справжній філософ. Коли ж він збирав навколо себе молодь і вів морально-повчальні бесіди про те, як слід жити (якщо він дійсно це робив), то тут він поставав, у першу чергу, вихователем, учителем чи наставником. Дещо перебільшуючи, можна сказати, що Сократ постраждав зовсім не за розвинуті ним філософські концепції, а за свою педагогічну діяльність.

В. Россман. Філософія без норм і оцінок, філософія суто описова, - це все одно, що філософія без власної думки, тобто те, чого ніколи не існувало. Норми мислення і поведінки, а також експлікація нормативних передумов різноманітних суджень є фундаментальним предметом філософського міркування. Сократ, Епікур, Сенека, Кант, Ніцше, безперечно, говорили не стільки про те, які існують звичаї, скільки про те, що має вважатися нормою і чому, і формулювали критерії для цих норм. Юм, Мілль, Кант, Фреге, Рассел, Карнап, Вітгенштейн також займалися тим, що може вважатися істиною, а що не може і чому саме.

Крім того, нормативність не означає, що норми довільно конструюють або вигадують на власний розсуд. I філософ ніколи не вивчає існуючі звичаї або практики використання істини, - цим займаються соціальні науки, - а саме намагається визначити ці норми і часто абсолютно апріорним способом. Нормативність передбачає, що ми говоримо про стандарти правильного мислення або поведінки. Геометри ніколи не говорять про стандарти правильної поведінки фігур, а тільки описують ідеальні об'єкти.

Я.Шрамко. Не впевнений, що тут дійсно має місце строга дихотомія - або нормативність, або «чиста описовість». Завдання теоретичного аналізу, зокрема й обгрунтування тих чи тих об'єктів і пов'язаних з ними закономірностей, не будучи по своїй суті нормативним, зовсім не зводиться до простого «фактофіксуючого» опису їх властивостей. Звичайно, опис існуючих звичаїв - це не справа філософа. Але так само не входить у його компетенцію і встановлення стандартів правильної поведінки. Щодо «правильного мислення», то зміст цього поняття мені не зовсім зрозумілий, мені здається, тут ми маємо справу із виразом у якомусь суто переносному значенні.

Говорячи про «історичне визначення філософії», тобто про те, чим фактично була філософія в ході свого розвитку, я хотів би нагадати слова Гуссерля, що саме «за своїм історичним завданням» філософія, як «представниця одвічних претензій людства на чисте й абсолютне 
пізнання» завжди позиціонувала себе «найстрогішою з наук» і завжди прагнула нею бути.

В. Россман. Наука - це явище Нового часу, і філософія, усупереч Гуссерлю, ніколи не була найстрогішою з наук.

Я. Шрамко. Але завжди прагнула нею бути. . .

В. Россман. Філософія виникає задовго до науки і науковий прогрес аж ніяк не скасовує її принципів і підходів. Тому філософії зовсім не обов'язково навіть у добу науки відмовлятися від свого права первородства. Філософія має справу з донауковими формами мислення, але це форми саме раціонального мислення. Кінець XIX - початок XX століть позначені спробами створення суто наукової філософії, коли весь попередній філософський розвиток було оголошено метафізикою. Проти філософії, яку стали називати метафізикою, озброїлися практично всі філософські школи - позитивісти, аналітики, марксисти і навіть феноменологи. Але думаю, що філософія, під якою я маю на увазі не лише нові наукові філософії, але й традиційну метафізику, не поглинається повністю наукою, філософія і нині залишається повністю автономною сферою стосовно науки, відтак не повинна в усьому підганяти себе під наукові стандарти. Проте і самі стандарти науковості трансформуються і набувають нових вимірів. Скажімо, теорія струн у фізиці мало відрізняється від філософії за своїм статусом і в плані можливої верифікації.

А втім, у строгому сенсі філософія і наука взагалі не $\epsilon$ конкурентами. Історично конкурентами філософії- а пізніше й науки - були міфологія і релігія, які поступово зазнали витиснення як моделі пояснення реальності. Багато філософських проблем і нині виникає в якихось наукових провінціях і розростається у філософські теорії: так було із структуралізмом, теорією еволюції, герменевтикою, системним підходом, логічним позитивізмом.

Я. Шрамко. Твердження, що філософія виникла раніше від науки, здається мені не таким вже й беззаперечним. У певному розумінні можна вважати, що все було з точністю до навпаки. Адже вже стосовно «першого філософа»-Фалеса не так легко вирішити, ким він був насамперед - філософом чи все ж таки вченим - дослідником природи, астрономом, геометром. До певного моменту «філософія» по суті була синонімом «науки», тому у творчості багатьох великих мислителів (тут доречно згадати того ж Аристотеля, а в Новий час - Декарта і Лейбніца) власне філософські аспекти завжди тісно перепліталися 3 конкретнонауковими. Та й за своєю формою побудови філософські 
концепції (онтологічні, теоретико-пізнавальні або етичні) аж до недавнього часу практично нічим не відрізнялися від математичних або фізичних теорій. Ще Шопенгауеру саме протиставлення філософії і науки видалося б просто безглуздим. Тому для мене поява і поширення, починаючи з другої половини XIX століття, різних «ненаукових форм філософії», знаменує якраз розрив з багатовіковою традицією сприймання й самоусвідомлення філософії як певного виду наукового знання. Говорити про те, що філософія і наука не є конкурентами значить допускати неточність, відому в логіці як «стрибок у поділі» (аналогічним було б твердження, що не є конкурентами наука і математика).

Слід ураховувати, що на початкових етапах розвитку розуміння філософії часто (хоча і не завжди) було двояким - разом з теоретичним осмисленням дійсності від неї нерідко очікували універсального рецепта ідеального способу життя, і в цьому практичному аспекті філософські концепції розглядалися як підгрунтя для «мистецтва життя». Характерним прикладом у цьому відношенні $є$ конфуціанство або, скажімо, стоїцизм. Годі й казати, що тепер ця «функція філософії» повністю відійшла в минуле подібно до наївних уявлень ранніх математиків про вплив чисел на людське життя. У ході свого розвитку філософія викристалізувалася в суто теоретичну дисципліну і будьякі спроби задіяти їі «безпосередньо прикладним» чином у наш час неминуче мають характер відвертого зловживання або вульгаризації. Сьогодні філософ, який дає поради, як «правильно жити», по суті уподібнюється нумерологу, що обчислює долю за датою народження. Це, звичайно, не означає, що результати філософського аналізу не можуть використовуватися в інших науках, навпаки, таке використання може бути дуже плідним. I тут знову доречно провести аналогію з чистою математикою.

В. Россман. Я не думаю, що ідея мистецтва життя так уже застаріла. Інша річ, що вона не укладається в параметри аналітичної філософії і «науки», радикальні формулювання якої- скажімо Віденського гуртка - $\epsilon$ не більш ніж експериментальною філософією, співставною, наприклад, із феноменом французького нового роману в контексті історії літератури. Принаймні сьогодні це виглядає саме так. Проект аналітичної філософії починався з розмови про здоровий глузд, але результат виявився насправді не менш ідеалістичним і незграбним, ніж гегельянство і платонізм, проти яких вони боролися. Аналітики намагалися створити особливу філософію для філософії подібно до теорії 
мистецтва для мистецтва. Проблема в тому, що питання про сенс життя зовсім не є суто науковим, але це питання, поза сумнівом, філософське. Людина, далека від науки, цілком здатна зрозуміти його та замислитися над ним, але навряд чи вона зможе знайти відповідь для себе у формулах наукових філософів. Філософія шукає не лише і навіть не стільки наукову істину, скільки матеріал і форми для побудови ідентичності людини, для якої суб'єктивність і поезія не менш важливі ніж будь-яка об'єктивність.

Я. Шрамко. Все ж хочу підкреслити, що я тут маю на увазі зовсім не аналітичну філософію, а філософію як таку. Питання про сенс життя, звичайно ж, відноситься до типових, можна сказати, класичних філософських питань. Але як виглядає філософський розгляд цього питання? Філософ піддає теоретичному аналізу саму проблему, виявляє і зіставляє різні ㄲï формулювання та можливі вирішення; такий аналіз має суто науковий характер. Але було б не лише наївним, але і просто невиправданим очікувати отримати від філософії якусь остаточну відповідь на порушене питання. Це просто виходить за рамки її компетенції.

Вище ви охарактеризували філософію як «особливу форму інтелектуального насильства». Наскільки така характеристика доречна, коли йдеться про філософію? Чи цей ваш вираз слід розуміти як поетичну метафору, сказану для «красного слівця»?

В. Россман. Чесно кажучи, я зовсім не вважаю красне слівце у філософії якоюсь надмірністю або чужинцем. Куці і несміливі обтічні формулювання, слизькі висловлення і різні інші еківоки компрометують філософію значно більше. Історично філософська мова завжди трималася на метафорах і красних слівцях. До того ж мою метафору нескладно пояснити найпростішими словами.

Філософія завжди протистояла міфології здорового глузду, претензіям буденного знання, з одного боку, і попереднім філософським концепціям, з іншого. Філософські інтерпретації зазвичай розширювали або деконструювали (задовго до появи деконструкції) конвенціональні уявлення й усталені, законсервовані культурою інтерпретації концепцій, і в цьому сенсі філософія, звичайно, завжди була формою насильства над текстами, свідомістю читачів, спробою дивитися за межі очевидностей. Історично філософія завжди була найбільш повнокровною і екзистенціальною наукою, і навіть найбільш наукові аспекти філософії- зокрема логіка та епістемологія - завжди були екзистенціально вмотивовані. Наприклад, епістемологія часто виступала прое- 
кцією політичних програм філософів, і це правило практично не знає винятків. Відповідно до закону єдності та симетричності епістемологічного і політичного, ліберали, зазвичай, тяжіли до сенсуалізму, авторитарні мислителі - до раціоналізму, тоталітарні - до ірраціональних ідей пізнання. Тут, звичайно, були різні нюанси, і я виражаю цю думку дещо грубо і надто соціологічно, але загалом, я переконаний у своїй правоті.

Я. Шрамко. Мені важко з вами погодитися. Сучасна, та й не тільки сучасна, фізика, природознавство взагалі, не меншою мірою протистоять здоровому глузду, ніж філософія. Уже геліоцентрична система Коперника була не чим іншим, як прямим запереченням буденних уявлень, які підтверджуються щоденним досвідом на рівні здорового глузду. Так само, наприклад, розходиться з елементарним здоровим глуздом і твердження Галілея, що прискорення вільного падіння не залежить від маси тіла. Крім того, при бажанні, нескладно виявити екзистенціальну складову і в теорії відносності, або теорії природного відбору, або навіть у теорії множин.

В. Россман. Це інша екзистенціальність. Ми не очікуємо, скажімо, від професора математики або фізики життєвої мудрості, якогось артистизму, відчуття стилю. Уже непогано, якщо це буде якась цікава особа. Але від філософа в нас є очікування певної харизми і артистичності. I такі очікування $є$ повністю легітимними, хоча, звичайно, вони далеко не завжди виправдовуються. У випадку учених екзистенціальні мотиви, звісно, також можуть мати місце, - скажімо, смерть рідних або батьків могли якось мотивувати відкривача пеніциліну, - але такі поштовхи завжди залишатимуться зовнішніми стосовно самих наукових теорій. Навряд чи можна стверджувати, що в теорії термодинаміки якось відбились особи Максвела і Резерфорда в тому ж розумінні, в якому особа Кіркегора або Канта втілилася в їхній філософії. Тому про філософію і можна говорити не лише як про науку, але і як про форму мистецтва. Часто важливе не тільки те, що говорять, а й хто і як говорить.

Я. Шрамко. Мені здається, тут відбувається своєрідна підміна понять, коли ми узагальнено говоримо про «фізиків», «математиків»або «філософів». Якщо вести мову про великих і неординарних фізиків або математиків, масштаб Ейнштейна, Капіци, Ландау, Пуанкаре або Колмогорова, то від них також абсолютно доречно і виправдано очікувати тієї харизми, про яку ви згадали, і вона обов'язково властива всім дійсно великим ученим. Звісно, «середній фізик» може такої харизми й 
не мати, але так само це справедливо й стосовно будь-якого «середнього» професора філософії. Проста причетність до професійної філософії (викладання філософських курсів в університеті, публікація статей у спеціальних філософських журналах тощо) сама по собі, звичайно ж, не може бути достатньою підставою для обгрунтування претензій на якусь особливу «харизматичність».

В. Россман. У науці, поза будь-яким сумнівом, є безліч яскравих осіб, й учені можуть бути і часто бувають оригінальними, цікавими людьми, екстравагантними та ексцентричними. Але їх наукові теорії, як я вже сказав, пов'язані з їх особою лише зовнішньо, а не внутрішньо. Безперечно, ви маєте рацію, що шапка Мономаха може виявитися заважкою або навіть недоладною у випадку рядових викладачів філософії. Філософи, як і великі учені,- штучний товар. Крім того, мені здається, що потенціал філософії як форми мистецтва ще недостатньо реалізований у самій історії філософії. Філософія могла б бути особливою виставою, яка супроводжується музикою, специфічними костюмами, пантомімою і декораціями. Але це тема окремої розмови.

На мій погляд, поетичне і наукове начало аж ніяк не є взаємовиключними. Філософія - це синтетичне мистецтво, як, скажімо, опера і може поєднувати в собі наукове і поетичне. Подібно до того, як в опері ми не можемо судити про ціле лише на підставі краси голосів, ігноруючи костюми, декорації, сценічну дію, так і в судженнях про філософію не завжди можна спиратися тільки на наукові критерії. Тому філософ передусім повинен запитувати себе, не наскільки спроможним ученим він виявляється у своїй філософії, а наскільки хорошим філософом. Платон хотів видворити поетів із своєї держави. Хайдеггер хотів видворити зі своєї філософської держави учених, які послуговуються мовою як інструментом. Мені здається, що у філософії є достатньо місця і для філософів-учених, і для філософів-поетів; та й самі філософиучені не завжди усвідомлюють, як багато поезії в їхній філософії.

Я. Шрамко. У цьому розумінні справжня наука також багато в чому споріднена з мистецтвом. Великі твори, що позначили віху в розвитку науки, такі як «Про обертання небесних сфер» Коперника або «Principia Mathematica» Уайтхеда і Рассела, при бажанні цілком можна назвати «науковими симфоніями». Математики дуже часто використовують своєрідний «естетичний критерій» для оцінки і характеристики тієї або тієї теорії або, скажімо, доведенні якоїсь теореми: якщо таке доведення $\epsilon$ «струнким», «витонченим», та й просто «красивим», то воно, швидше за все, виявиться правильним і із строго математи- 
чної точки зору. Абсолютно правомірно вести мову, скажімо, про «математичне мистецтво» або про «поезію хімічних формул». I це далеко не завжди є лише образними виразами. Але тим самим математика і хімія аж ніяк не перетворюються на різновид мистецтва або поетичної творчості, якщо лише не розуміти мистецтво і поезію в гранично широкому сенсі. Так само справедливо це і для філософії.

В. Россман. У найширшому сенсі вся людська культура поетична. Мова - стихійний поет і діалектик, і різниця між різними сферами культури стосовно поезії швидше кількісна, ніж якісна. Поетичні мотиви й метафори пронизують всю сферу людського буття, і в цьому розумінні наука не менш причетна до поезії. Отже, можна говорити не лише про наукові, а й, скажімо, про кулінарно-гастрономічні симфонії. Перефразуючи італійську приказку, можна сказати, що сонце опера бідняка. Проте для філософії, на відміну від науки, поезія $є$ одним з внутрішніх критеріїв її спроможності. Необхідно підкреслити, що філософія може наближатися до поезії не за статусом своїх результатів і не за точністю виразів, але за способом продукування концепцій. Філософія займається цілим, і такі критерії, як гармонія і узгодженість частин, безперечно, надзвичайно для неї важливі. Певна річ, деякі глобальні наукові теорії переростають у філософські, і ï також можна вважати поетичними. Але поетичність як така більш властива саме філософії.

Я.Шрамко. Гармонія та узгодженість частин, звичайно ж, важливі для філософії. Але не менш важливі вони для математики і теоретичної фізики, які також зайняті розглядом цілого. Все ж, на мій погляд, ми швидше зможемо виявити специфіку філософії не шляхом зіставлення ㄲï з науковим знанням, а спробувавши позначити її місце стосовно інших наук.

В. Россман. Ціле філософії має більш глобальний характер. Турецький поет Назим Хікмет назвав якось поезію «найкривавішим 3 мистецтв». Я сказав би, що філософія завжди була найкривавішою 3 наук. Не лише тому, що вона намагалася змінити світ, і не лише тому, що багато найкривавіших політичних режимів живилися і надихалися деякими філософськими ідеями. Прикладами тут можуть бути різні концепції марксизму від Леніна до Пол Пота і Мао Цзедуна, філософські пристрасті нацистів, зловісний професор філософії Гусман, вождь терористичної організації Sendero Luminoso, що мріяв про відтворення в перуанських джунглях імперії інків, різноманітні терористичні організації, які надихалися філософськими ідеями. I багато крупних фі- 
лософів були схильними до таких взаємовідносин: Сартр прийшов до виправдання тероризму, Фуко імпонували акції аятоли Хомейні, Хайдеггер охоче відгукнувся на заклик націонал-соціалізму, Лукач служив червоним комісаром. Але головне тут не це, а те, що підгрунтям філософських ідей, навіть, здавалося 6 , ціннісно-нейтральних, були певні уявлення, схильність до певних цінностей і потужний екзистенціальний заряд. Такий стан речей характерний не лише для континентальних філософів, але й для предстаників багатьох аналітичних підходів. Надзвичайно екзистенціальними $є$ Карл Поппер, Людвіг Вітгенштейн, Карнап, Селларс, не говорячи вже про представників тих сучасних напрямків аналітичної філософії, які переварили і абсорбували прагматизм.

Я. Шрамко. Не впевнений, що філософія має хоч якесь відношення до націонал-соціалістичного ентузіазму Хайдеггера. Своєю співпрацею з нацистами Хайдеггер зганьбив лише себе, але ніяк не філософію як таку. Щодо Пол Пота і Карла Маркса, то якщо теорія марксизму i несе долю вини за геноцид у Камбоджі і жахіття Туол Сленга, то перш за все і навіть виключно як соціально-політична доктрина, хоча можна й посперечатися, якою мірою «революційна практика» червоних кхмерів відповідала дійсним уявленнями Маркса про справедливий суспільний устрій. Проте в будь-якому випадку суто філософська складова марксизму політично $є$ абсолютно нейтральною. Не можна стверджувати, що уявлення про первинність матерії і її всезагальний діалектичний розвиток неминуче прозводить до тоталітарних суспільно-політичних переконань. Не так вже й важливо, чим надихалися й надихаються різного роду терористи і диктатори, тут можуть бути чудернацькі та несподівані поєднання. Як відомо, Гітлер зачитувався пригодницькими романами Карла Мая, проте навряд чи буде справедливим на цій підставі покласти на останнього яку б то не було відповідальність за злочини нацизму. Так само той факт, що деякі німецькі фізики в Третьому Рейху активно долучилися до проекту створення атомної бомби або відстоювали ідею «арійської фізики», навряд чи кидає криваву тінь на фізику як таку.

В. Россман. Ви тут дуже вдало навели аргументи проти ідеї виняткової відповідальності філософії за дії тих чи тих політичних режимів, і я з ними повністю погоджуюся. Але я не відокремлював би філософію від політичної доктрини, а якби й відокремлював, то зв'язок суто філософської і соціально-політичної складових світогляду в мене, можливо, був би прямо протилежним. Висловлена мною рані- 
ше думка про симетричність епістемологічних концепцій і політичних програм начебто підтверджує таку позицію. Крім того, політична ангажованість філософа або відсутність такої, на противагу заангажованості вченого, $є$ іманентною частиною його філософії. 3 тієї ж причини навряд чи коректною буде аналогія між захопленням Гітлера пригодницькими романами і прихильністю певного політичного діяча до якоїсь конкретної філософії. Звичайно, виводити політичну доктрину із захоплення пригодницькими романами, манері сидіти на стільці або пристрасті до собак (Гітлер любив собак) досить абсурдно. Але пов'язувати її з філософською позицією цілком правомірно, хоча такий зв'язок не завжди буває прямолінійним.

Я.Шрамко. Так, але у вас йшлося не стільки про філософські позиції політичних діячів, скільки про політичні погляди і схильності деяких філософів. I якраз взаємообумовленість останніх для мене $\epsilon$ не такою вже очевидною. Продовжуючи вашу аналогію, я сказав би, що зв'язок між діалектичним матеріалізмом та ідеєю масових розстрілів класово чужих елементів приблизно такий же, як і зв'язок між кінологією і націонал-соціалістичною ідеологією.

В. Россман. Проте, повторюсь, кривавий характер філософії обумовлений не стільки родоводом кривавих ідеологій, - хоча тут є тема для окремої розмови, - а самою орієнтацією філософії на цінності і її екзистенціальним характером. Усупереч одинадцятій тезі про Фейєрбаха, ідея про суто споглядальний характер філософії- плід непорозуміння. Звичайно, в історії філософії були достатньо споглядальні філософи - скажімо, Аристотель і Спіноза, - але там було значно більше активних мислителів, які виступали з розгорнутими програмами перебудови світу: Плотін, Руссо, Конт.

Я.Шрамко. Ви маєте рацію, філософ цілком здатний висунути програму радикальної перебудови світу, і багато філософів навіть убачали в цьому свій обов'язок перед людством. Проте, я переконаний, як тільки філософ бере на себе роль перетворювача дійсності, нехай навіть на рівні чистого соціального проекту, він тим самим неминуче виходить за межі власне філософії і вступає в сферу політики або ідеології. «Держава» Платона - великий соціально-філософський твір, але таким він $є$ зовсім не тому, що нібито пропонує певний план досягнення ідеального державного устрою, а завдяки тому, що тут уперше в систематизованому вигляді досліджуються загальні сутнісні характеристики держави як такої і здійснюється теоретичний аналіз ключових категорій, на які взагалі спирається ідея людського соціу- 
му, таких як справедливість, суспільне благо і т.ін. I хоча положення, сформульовані в «Державі», неодноразово слугували «філософським базисом» для революційних проектів перетворення суспільства, це вже проблема використання наукового знання, спільна для всіх наук. Проект розробки атомної бомби виходить за рамки ядерної фізики, хоча без відкриття поділу атомного ядра побудова атомної бомби була б і неможливою. Звичайно, у філософії, як і в інших теоретичних науках, існують і власне прикладні розділи, наприклад у політичній філософіiі, де можуть формулюватися якісь більш-менш конкретні «практичні рекомендації», але така перетворювальна роль філософії подібна, наприклад, до перетворювальної ролі біології і генетики, використання досягнень яких дозволяє отримати нові сорти зернових або збільшити врожайність. Так само філософ може брати безпосередню участь у політичній діяльності (приклад тут, як відомо, подав сам Платон, що подвизався в Сіракузах при обох Діонісіях), проте в цьому випадку він менше від усього постає як філософ. Чимало видатних учених набагато успішніше від Платона поєднувало наукову роботу з політичною діяльністю (тут можна пригадати Лазаря Карно, Вільгельма фон Гумбольдта або Франсуа Арго), при цьому відстоюючи і втілюючи в життя ті або ті цінності, але це не додає якоїсь особливої екзистенціальності математичному аналізу або класичній філології.

Мені не хотілося б, аби мої зауваження сприймалися лише як дріб'язкові й неістотні нападки. Головна думка, яку я намагаюся підкреслити і яку я вважаю дуже важливою, полягає в тому, що філософія не $\epsilon$ чимось абсолютно винятковим. Перефразовуючи Локка, можна було б сказати, що у філософії немає нічого такого, що якоюсь мірою не було б властиве й іншим наукам. Філософія $€$ «всього лише» однією з наук - не більше, але й не менше. Вона, звичайно ж, має власну специфіку, але так само своя специфіка притаманна й будьякій іншій науці. Подібно до кожної науки філософія має в своєму розпорядженні особливу предметну область, дослідженням якої вона мусить займатися, й особливі методи, за допомогою яких таке дослідження здійснюється. Та це, звісно, не дає їй права претендувати на якусь винятковість, адже в цьому вона швидше схожа на інші науки, аніж відрізняється від них. Для мене заперечення наукового статусу філософії - дуже популярне останнім часом - $є$ безперечною ознакою занепаду. Філософ не може і не повинен виступати в ролі якогось «учителя життя», мудреця, що претендує на те, щоб повчати всіх і вся, як належить мислити і чинити у всіх (або в окремих) можливих випадках. Такі претензії $є$ не просто необгрунтованими, вони багато в чому 
межують з (вільним або невільним) шарлатанством, яке не має нічого спільного із справжньою філософією. Філософія не може і не повинна визначати «дійсні цінності» або виробляти «справжній світогляд»стверджувати зворотнє було б щонайменше нескромно.

В. Россман. Проте, я вважаю, що філософія неминуче виступає за певні цінності, незалежно від інтенцій філософів, і за стінами університетів вона цікава саме системою цінностей. Що стосується шарлатанства, то воно може виникати й часто виникає і на грунті самої науки. Тут доречно провести аналогію з ціннісними посилками, на яких базується політичний устрій суспільства. Останній ніколи не буває і не може бути абсолютно ціннісно нейтральним, у нім завжди втілена якась концепція добра. Лібералізм часто бачить або точніше бачив себе ціннісно нейтральною ідеологією, але насправді він проводить абсолютно конкретну ціннісну програму. Те ж саме спостерігаємо й у філософії. Навіть наші когнітивні дистинкції, а часто і фактичні судження вже мають ціннісний характер. У цьому сенсі аналітична філософія є такою ж ціннісною програмою, як і будь-яка континентальна філософія, але, на відміну від останньої, часто відмовляється її визнавати. Філософія займається насамперед цінностями, виконуючи свою головну критичну функцію. Тут я згоден швидше з Ніцше, ніж із Юмом.

Щодо особливих претензій філософії. Філософія природним чином знаходиться ніби в центрі кола інших дисциплін просто завдяки масштабу проблем, які розглядаються нею, і через характер свого матеріалу. I природним чином займає верхню позицію в «харчовій піраміді» знання. Інші науки виступають при цьому у вигляді сировини для філософських концепцій. Спроби сучасної аналітичної філософії сховатися від цієї місії і перетворити філософію на суто спеціальну науку нагадують відому біблейську притчу про Іону та кита. Нагадаємо, що Іона прагнув стати просто звичайною людиною і відхилитися від своєї місії. Філософія - це щось на кшталт брокерської служби знання. Мова філософії є сворідним есперанто для мов усіх наук і мистецтв. Вона є місцем перетину різних здібностей, видів знання і досвіду. I це стає можливим саме завдяки тому, що філософія $є$ не лише системою знання, але й формою досвіду. Жодна інша наука не $є$ нормативною. У жодній іншій науці дві принципово протилежні точки зору не можуть бути однаково легітимними (а не просто правдоподібними).

Однак така її позиція - хочу це підкреслити - на мій погляд зовсім не припускає, що філософія обов'язково $є$ вищою формою знання. Я говорю тут про винятковість цілком зриму й очевидну, але в значенні 
особливості, а не у значенні якоїсь вищої й авторитетнішої сукупності знань, на яку всі повинні орієнтуватися.

Я. Шрамко. Якщо розуміти винятковість як особливість, то тут я повністю з вами згоден. Як і будь-яка інша галузь знання, філософія має свою особливу неповторність. Хоча, повинен сказати, мені невідомі згадувані вами аналітичні філософи, які нібито прагнуть перетворити філософію на суто спеціальну науку. Не зовсім зрозумілий той смисл, який ви вкладаєте в поняття «суто спеціальної науки». Чи належить до таких наук математика? Вочевидь, математика $€$ чимось більшим, ніж якась спеціальна наука на зразок фізіології рослин. I до математики цілком можна застосувати ваші слова про центральне місце стосовно інших дисциплін. Проте це зовсім не ставить під сумнів науковий статус математики і не дає нам підстави приписувати їй якусь вселенську місію. Так само не може претендувати на таку місію і філософія.

В.Россман. Під спеціальною наукою я розумію суто службову, обслуговуючу функцію в системі наукового світогляду, скажімо, зведення філософії до аналізу мови. Через спеціалізацію і фрагментацію знання філософія перестала справлятися із загальними завданнями, втратила відчуття і бачення цілого й почала аналізувати окремі парадокси і софізми. Софізм, по суті,- це і $є$ аналіз якогось питання, вирваний з контексту і бачення цілого. Як наслідок, філософія перетворюється із системи в комплекс модулів знання в різних розділах філософії.

Повертаючись до питання про претензії філософії, можна сказати, що історично вони певним чином закономірні. Віндельбанд порівняв сучасний йому стан філософії з королем Ліром, який віддав весь свій статок дочкам. Мені видається, що, враховуючи специфічно російський і частково німецький контекст, тут більш доречною була б аналогія з імперією, від якої відкололася безліч частин-лімітрофів. Історія культури постає в цьому контексті як історія боротьби, протистояння і різних альянсів між наддержавами - Міфологією, Релігією, Філософією і Наукою. Приклад альянсу філософії з міфологією - Плотін або Герміст Плетон. Приклад альянсу з релігією - Фома Аквінський або російська релігійна філософія. У новий час найбільш довгостроковим і міцним був альянс філософії з наукою, стосовно якої вона поставала історично як метрополія. Та в різних країнах стосунки між цими наддержавами складалися по-різному. В англосаксонських країнах філософія ніколи не підминала під себе весь корпус знань, а в російсько- 
німецькому контексті вона тривалий час пригнічувала інші науки. Як на мене, філософії слід відмовитися від своїх імперських амбіцій, проте, вважаю, вони аж ніяк не змінять її центрального географічного розташування.

Я.Шрамко. Чесно кажучи, порівняння філософії з імперією не здається мені особливо вдалим. I в Німеччині, не кажучи вже про Росію, філософія ніколи не займала домінуючого положення стосовно інших наук. Маю підозру, що таке домінування - це міф, активно підтримуваний самими філософами. Так, навіть у період найбільшого розквіту і політичного впливу вершини німецького ідеалізму - філософії Гегеля - представники інших наук не сприймали серйозно спроби самого Гегеля втрутитися в дискусії фізиків, хіміків або астрономів і просто ігнорували його судження з цих питаннь.

Узагалі, на мій погляд, будь-які претензії на винятковість у дусі якоїсь великої месіанської ролі, яку нібито покликана виконувати філософія, і з якими, на жаль, доводиться стикатися з боку окремих членів нашого цеху, по суті, є згубними для філософії. Багато в чому, саме такі претензії і викликають цілком очікувану реакцію відторгнення з боку представників інших наук, коли дилетанти і неуки іменем філософії намагаються повчати справжніх добросовісних учених, як їм належить правильно жити і мислити, що є людина і як «насправді» влаштований світ взагалі і їхні науки зокрема. Як наслідок, лунають заклики взагалі вилучити філософію з переліку обов'язкових дисциплін вищої школи. Наскільки виправданими $\epsilon$, на ваш погляд, такі пропозиції? Яким чином філософія може бути корисною вчителю, інженеру, фінансисту?

В. Россман. Філософія не $\epsilon$ формою знання, підзвітною науці, і не $\epsilon$ чимось зовнішнім стосовно неї. Сама концепція науки базується на суто філософських підставах. Лікарю-дерматологу добре було б знати загальну анатомію. Так само будь-якому фахівцю у нагоді стане розуміння системи загальних принципів і категорій. Філософія - це, крім іншого, і мистецтво ставити запитання, і таке уміння $\epsilon$ корисним далеко за межами чистої філософії. Але найбільш важливою мені уявляється роль філософії в побудові власної ідентичності і гармонійному розвитку особистості. Викладач філософії в певному сенсі стає медіатором між культурою і цивілізацією. У дикорослих формах філософія не дуже-то і вписується в контекст університетської практики, оскільки в ній надто сильний елемент боротьби з ідолами та ідолопоклонництвом. Такий досвід $\epsilon$ необхідним для всіх людей, причетних до освіти. 
Професори намагаються приручити філософію і включити її до системи культури, зокрема й науки.

Я. Шрамко. Інакше кажучи, ви вважаєте, що філософія покликана виконувати в системі вищої освіти цілком особливу місію і місія ця має насамперед виховний та світоглядний характер («гармонійний розвиток особистості»), і саме як такий інструмент виховання філософія повинна включатися до навчальних планів усіх спеціальностей? У мене $\epsilon$ відчуття, що таке визначення місця філософії в системі вищої освіти багато в чому співвідносне з тими завданнями, які за радянських часів ставилися перед «марксистсько-ленінською філософією» у справі виховання «справжнього будівника комунізму» i формування відповідного світогляду.

В. Россман. Я не використовував би ці вирази, але суть, якщо завгодно, саме в цьому. Не думаю, що загальногуманістичні установки марксизму, які сягають своїм корінням ідеалів німецького романтизму Шиллера і Гете, хоч якось застаріли, навіть якщо їх замацали і затягали.

Я. Шрамко. На жаль, філософія часто розглядалася переважно як засіб для досягнення тих чи тих ідеалів, нехай навіть і найбільш піднесеного характеру. Я назвав би таке уявлення про роль філософії інструментальним. Але наскільки взагалі виправдано інструментальне розуміння філософії? До того ж, чи доречно загалом ставити перед університетом завдання «всебічного розвитку особистості» студента? Для мене ці питання цілком риторичні, і негативна відповідь на них очевидна. Людина вступає до вищого навчального закладу для того, щоб отримати певну суму знань і набути відповідної кваліфікації згідно з обраною спеціальністю. Що ж до особистісного розвитку, то це супутній (і постійний) життєвий процес, здійснення якого можливе, зокрема, і підчас вивчення навчальних дисциплін. Знову ж таки філософія в цьому аспекті нічим не відрізняється (або принаймні не повинна відрізнятися) від будь-якого іншого предмета університетського курсу. Тому роль викладача філософії по суті зводиться до того ж, що й викладача математики або історії- передати студентам певні знання зі свого предмета.

Інше питання - чи потрібні філософські знання майбутньому інженеру, а якщо так, то в якому обсязі? Як на мене, «філософський мінімум» $\epsilon$ необхідним компонентом вищої освіти за визначенням. Починаючи 3 певного рівня, опанування будь-якої спеціальності, особливо якщо йдеться про теоретичний, а не лише ремісницький рівень тако- 
го оволодіння, передбачає знайомство з фундаментальними філософськими категоріями. Так, справжній фізик повинен мати уявлення про поняття субстанції, матерії як такої і про історію розвитку цих категорій, усвідомлювати проблемний характер взаємовідношення понять «причини» і «наслідку». Кваліфікований історик має ознайомитися 3 дискусіями $з$ проблеми «кінця історії» або стосовно можливості існування «законів розвитку суспільства». Не говорячи вже про обов'язковість для будь-якого фахівця з вищою освітою певного «загальнокультурного багажу», надбанню якого значною мірою сприяє змістовний загальний курс філософії.

В. Россман. Не думаю, що це дуже відрізняється від світогляду, i також не бачу нічого особливо інструментального в своєму підході...

Я.Шрамко. У зв'язку з цим, як ви вважаєте, наскільки сучасній філософській думці на пострадянському просторі вдалося відійти від «марксистсько-ленінських» штампів, які, здавалося б, в”їлися в їі плоть і кров, і чи відповідає вона тому рівню вимог (зокрема, якщо орієнтуватися на світовий рівень), якому вона повинна була б відповідати, аби мати право пропонувати свої послуги представникам інших галузей?

В. Россман. Спробую обмежитися своїми враженнями від російської філософії, оскільки я мало знайомий із сучасною українською або, скажімо, казахською філософією, хоча і можу припустити, що там відбуваються аналогічні процеси. Насамперед слід зазначити, що за минуле двадцятиріччя в російській філософії сталася безліч позитивних змін, з'явилося немало добротних і кваліфікованих перекладів і в якихось аспектах ситуація наблизилася до світової. Але $є$ й безліч екзотичних моментів. Мені здається, тут до цього часу не сформувався якийсь єдиний контекст і формат дискусій. У книгарнях інтелектуальної літератури впадає в очі жахливе засилля мислителів 30-х років минулого століття - Зомбарт, Шпенглер, Хайдеггер, Карл Шмітт, Юнгер, Евола, Батай, Ортега-і-Гассет, Бланшо та ін. - мабуть, найбільш актуальних у Росії станом на сьогодні. Мабуть, відразу за ними за рівнем популярності слідують різнокаліберні, генетично пов'язані з мислителями 30-х років пост-модерністи: Фуко, Дельоз, Дерріда та інші. У негласній інтелектуальній ієрархії саме цей тип мислителів, імовірно, посідає нині перше місце. Проте світовий філософський консенсус 3 приводу постмодернізму полягає сьогодні в тому, що це щось не зовсім їстівне і далеко не завжди корисне. У радянські роки логічний імунітет російської культури настільки послабшав, що галльський пустоцвіт 
постмодернізму зумів легко проникнути до самого центру крихкого пострадянського інтелектуального життя і розпуститися потворними, немічними, другосортними квітами. Ослаблені багаторічною ідеологічною муштрою, пострадянські мізки, ласі до всього французького й особливо до всього малозрозумілого, виявилися занадто піддатливими для цього небезпечного і хмільного французького зілля. Але навряд чи такого типу філософствування можна назвати вдалим прикладом для наслідування. Французький письменник і мораліст XVIII століття Антуан де Рівароль якось сказав: «Ce qui n'est pas claire n'est pas française» («Все, що висловлено неясно - не по-французьки»), і це відображало інтелектуальну ситуацію у Франції тих часів. На жаль, розпізнавальним знаком більшості із сучасного французького інтелектуального доробку, що з'являється на російському ринку, стала саме неясність, нечіткість і логічна неохайність.

Я. Шрамко. Мене непокоїть також і та проблема, що деякі наші автори навчилися дуже вправно імітувати філософський дискурс, видаючи своє барвисте марнослів'я мало не за останнє досягнення світової філософської думки. У їхньому виконанні філософська діяльність зводиться до вмілого жонглювання вигадливими термінами, а філософський текст набуває вигляду більш-менш майстерно оформленого хитросплетіння витіюватих слів, за якими, проте, не міститься жодного реального змісту. Таких текстів, на жаль, стає все більше, й іноді саме по ним доволі поспішно судять про характер сучасної філософії. Слід визнати, що саме постмодерністська література надає особливо благодатного грунту для такої мімікрії.

В. Россман. Але що особливо прикро, ми практично не бачимо, хоч би для балансу і в якійсь пропорції їхніх опонентів, нудних раціоналістів і лібералів, які в книгарнях представлені набагато скромніше.

Я.Шрамко. I це загалом не так уже й дивно, ураховуючи, що раціоналісти й аналітики не настільки привабливі як об'єкти для можливої імітації. Так, аналітична філософія, з огляду на свій характер i наукову установку, націлена на раціональне трактування реальних і цілком конкретних філософських проблем, тому тут важко уникнути розмови по суті, а значить, значно складніше сховатися за димовою завісою беззмістовної термінології. Знову ж таки, на відміну від усілякої інтелектуальної містики, яка уміло виряджається в псевдофілософський одяг.

В. Россман. Таку література, назвемо її постмодерністською, на 
Заході відносять швидше до розряду маргінальної, в Росії ж вона належить до mainstream. Виходить, що інтелектуали країни, де традиції раціонального мислення ще не цілком сформувалися й зміцніли, де форми ліберальної думки і демократії не затвердилися, поголовно читають класиків антилібералізму. У цьому, звичайно, є й певна закономірність. Французькі мислителі підхоплюють факел цієї думки в німців після другої світової війни, а росіяни переймають його у французів після перебудови i, як мені видається, стають його єдиними на сьогодні законними спадкоємцями. Імовірно, зараз Росія є найбільш постмодерністськи інтелектуально орієнтованою країною в світі. Але я не впевнений, що можна так просто перестрибнути через модерн.

Цікаво, що всі найвизначніші російські мислителі були ідеологами Контр-Просвітництва - Толстой, Достоєвський, Флоренський, Леонтьєв, Розанов. Критика Просвітництва і лібералізму в країні, якої ще не достатньою мірою торкнувся сам вогонь Просвітництва (з його плюсами і мінусами), видається однобокою і значно відрізняється за своєю спрямованістю і змістом від аналогічної критики на Заході. $\mathrm{y}$ російському контексті така критика наче нічому й не протистоїть, а лише підтверджує старі автохтонні анти-раціональні й анти-ліберальні ідеї і рефлекси, якими рясніє ідеологія самого російського Контр-Просвітництва і які сприяють апології власної відсталості, підтримуючи феодальний каркас всієї системи. Нерв як постмодерністської філософіï загалом, так і російської ідеології Контр-Просвітництва - у запереченні універсальних законів мислення, релятивізації категорій, які підводять до думки, що Росія настільки унікальна, що тут взагалі не діють універсальні соціальні і логічні закони. Тому мені видається вкрай несприятливою тенденція визначати підгрунтям філософської освіти напрацювання мислителів 30-х років, які, безперечно, самі по собі є надзвичайно багатими і цікавими. У парламенті країни корисно мати декілька есерів і анархістів, та ситуація може стати фатальною, якщо вони складуть більшість. Як цікавий соус ці напрацювання можуть бути доволі пікантними, але все ж таки в меню необхідно мати хоча б кілька основних блюд, для яких цей соус має слугувати приправою.

Залишається актуальною і проблема зв'язку часів. У Росії часто друкуються твори, які на Заході вже давно вийшли з наукового обігу (що, звичайно, не знецінює їхньої історичної ваги і не заперечує доцільності перевидання), але тут навколо них виникають якісь несподівані ідеологічні турбулентності і малозрозумілі для стороннього ока дискусії, а іноді навіть і своєрідні культові рухи. 
Іншою проблемою мені видається монологічність та зависання текстів поза живою дискусією. Замість діалогу ми часто бачимо перекази з рефератами. Не так багато якихось творчих листувань у дусі, скажімо, листування «із двох кутів» між Гершензоном та Івановим. На Заході філософія тривалий час запліднювалася дискусіями між Хайдеггером і Карнапом, Патнемом і Рорті, Фуко і Хомським, Роулзом, Макінтайром і Нозіком або Дерріда і Гадамером. Подеколи дискусії між двома філософами бували не менш захоплюючими, ніж боксерський поєдинок. Напевно, і навчальний процес без такого боксерського компонента може виявитися млявим, нудним і непов'язаним.

Я. Шрамко. 3 приводу нашої філософської освіти хотілося б також зазначити, що вона до цього часу значною мірою несе на собі відбиток колишніх підходів, що дістався у спадок від радянських часів. Це проявляється, наприклад, у структурі і змісті більшості навчальних посібників або в характері задіяної філософської термінології. Дещо огрублюючи і усереднюючи реальну ситуацію, можна стверджувати, що у таких країнах як Росія й Україна багато філософів все ще дивиться на світ крізь призму «безкомпромісної боротьби матеріалізму з ідеалізмом». Часто це навіть не усвідомлюється, але такий погляд закладається вже на рівні поняттєвого апарату, оскільки система основних термінів, які приймаються в курсі філософії, не лише вирішальним чином визначає структуру курсу, але й справляє істотний вплив на його зміст. Сама термінологія, що використовується в різноманітних курсах філософії, які читаються зараз у вищих навчальних закладах Росії, України і багатьох інших країн, що утворилися на теренах колишнього СРСР, в основному (явно або неявно) продовжує термінологічну традицію марксистсько-ленінської філософії радянського зразка (діалектичний та історичний матеріалізм). Хоча багато понять інтерпретується тепер «нейтрально» й «об'єктивно», у дусі відмови від минулих ідеологічних оцінок і з урахуванням їхнього первинного змісту (типовий приклад - реабілітація терміна «метафізика»), проте сама термінологічна система наших філософських курсів переважно відтворює схеми радянських підручників тридцятирічної давності. Слід визнати, що термінологічна традиція радянської філософії мала певне нашарування архаїчності, розвиваючись значною мірою автономно, незалежно від світової традиції останнього століття, а часто і на противагу ій. Можна стверджувати, що пострадянській філософії поки що не вдалося до кінця подолати цю ізоляцію.

В. Россман. Багатьом нині здається, що доступ до філософської 
класики і текстів кардинально змінить ситуацію. Але досвід показує, що лише сам доступ до них не міняє інтелектуального ландшафту автоматично. Це нагадує ситуацію, коли людина середнього віку і з не дуже вправною атлетичною статурою раптом отримує доступ до новітніх спортивних знарядь. При цьому якась частина знарядь під час транспортування зробилася непридатною,-я маю на увазі переклади, - а деякі нібито новітні прилади виявилися насправді застарілими тренажерами, які звідкись списали, хоча й привезли під виглядом новітніх. Відтак не дивно, що чимало атлетів, які жадібно кинулися на ці знарядля, отримує травми. Філософія, як і музика, вимагає частих репетицій, підтримки м'язового тонусу, планомірної логічної підготовки, які можуть вберегти від дилетантизму та ілюзій, що у філософії можна нібито досягти великих відкриттів простим використанням новітнього допоміжного устаткування. Проте, незважаючи на труднощі, ситуація поступово вирівнюється.

Якщо говорити про світову філософську ситуацію, то можна зазначити, що ми живемо в добу сплавів у філософії. Її найбільш примітною рисою $є$ прихований синтез попередніх філософських традицій, що майже не перетиналися, - передусім континентальної та аналітичної, - які тривалий час були монадично замкнутими і здавалися майже різними дисциплінами. Виникають цікаві сплави між, скажімо, феноменологією і британським емпіризмом, виявляються перетини між найрадикальнішими напрямками аналітичної та континентальної філософії (наприклад, між Сартром і Муром). Це дуже позитивний процес: аналітична філософія має відмовитися від деякої властивої їй вузькості, а континентальна філософія - почати говорити більш розбірливою мовою. Наш час - це своєрідна стадія еллінізму у розвитку цивілізації, епоха, коли відбуваються безпрецедентні процеси конвергенції локальних усталених наукових і філософських традицій. 